Scientific Publications, Oxford, 1992.

3) Ruiz-Maldonado R, Lopez-Matinez R, Chavarria P, Castanon L, Tamayo L: Pityrosporum ovale in infantile seborrheic dermatitis. Pediatr Dermatol 6: 16-20, 1989.

4) Broberg A, Faergemann J: Infantile seborrheic dermatitis and Pityrosporum ovale. Br J Dermatol 120: 359-362, 1989.

5) Tollesson A, Frithz A, Stenlund K: Malassezia furfur in infantile seborrheic dermatitis. Pediatr Dermatol 14:
$423-425,1997$

6）清 佳浩, 中林淳浩, 森下宣明, 滝内石夫 : 乳児脂漏性皮 虚炎一特に常在菌のうち癜風菌の変動について一. 日小 皮会誌 19: 165-168，2000.

7) Nakabayashi A, Sei Y, Guillot J: Identification of Malassezia species isolated from patients with seborrhoeic dermatitis, atopic dermatitis, pityriasis versicolor and normal subjects. Med Mycol 38: 337-341, 2000.

\title{
Relationship between Malassezia Yeast and Infantile Seborrhoeic Dermatitis
}

Atsuhiro Nakabayashi, Yoshihiro Sei

Department of Dermatology, Showa University Fujigaoka Hospital, 1-30 Fujigaoka, Aoba-ku, Yokohama 227-8501, Japan

We examined 52 patients with infantile seborrhoeic dermatitis (ISD) and 47 healthy 1-month-old infants. Yeast cells on the right side of the face were counted by direct microscopic examination, and isolates from the left side of the face were identified by Tween test. Yeast cells were more numerous patients with ISD than in the healthy infants. $M$. furfur and $M$. globosa were isolated from ISD patients at significantly higher rates than from healthy infants.

\section{Malassezia sympodialis による中心静脈カテーテル 感染症の 1 例}

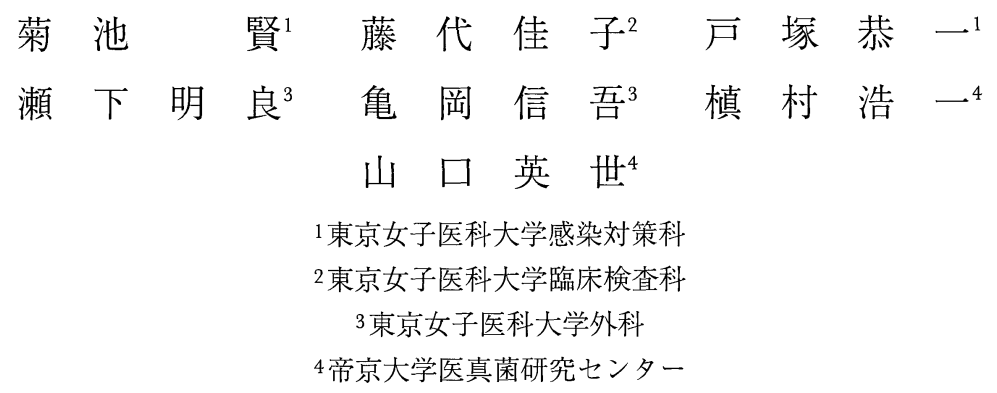

Key words: Malassezia sympodialis, 中心静脈カテーテル感染症 (central venous catheter-related infection), internal transcribed spacer region 1 (ITS1), 脂質要求性 (lipid requirement)

\section{序文}

Malassezia はヒトを含む恒温動物の皮膚に常在菌叢を 形成する一方で，癜風，毛包炎，脂漏性皮膚炎の原因と して知られている11. 最近では中心静脈カテーテル感染 症の起因菌としても報告が見られる ${ }^{11}$.ヒトでの感染例

別刷請求先 : 菊池 賢

干162-8666 東京都新宿区河田町 8-1

東京女子医科大学感染対策科
の多くは M. furfur か M. pachydermatis であり，それ以外の 菌種はほとんど報告されていない1)。しかし，Malassezia は近年, 脂質要求性の新しい 5 菌種を加えた 7 菌種に再 分類されて扔り 2), 従来, $M$. furfur とされてきた菌も別 種となる可能性がある。 今回，我々は文献上今まで報告 のみられないM. sympodialis による中心静脈カテーテル 感染症を経験し，検出菌の性状に興味ある知見を得たの で報告する。 


\section{症例}

患 者: 63 歳, 男性.

主 訴 : 右側腹部痛.

既往歴: 30 歳, 胃潰瘍で胃部分切除（Billroth II 法）, 53 歳, 自然気胸.

家族歴 : 特記すべきことなし.

現病歴: 平成 12 年 2 月から右側腹部痛あり, 気胸でか かっていた呼吸器外科より同年 4 月 9 日に一般外科に紹 介された. 上部消化管内視鏡にて残胃に Borrmann II 型 胃癌が見つかり，7月1日手術目的で入院となった．

現 症: 身長 $166.8 \mathrm{~cm}$, 体重 $56.0 \mathrm{~kg}$, 体温 $35.7^{\circ} \mathrm{C}$, 血 圧 $117 / 60 \mathrm{mmHg}$, 腹部に手術創瘏痕あるが, 他に特記す べき所見なし，感染症を思わせる所見, 曒風を疑わせる 皮䖉所見なし。

経 過: 平成 12 年 7 月 9 日胃全摘術施行し, 術後経 過も良好であった，術前に右内頸静脈に中心静脈栄養 (IVH) カテーテルが挿入された. 脂肪製郕は投与され ていなかった. 術中, 術後予防投与に cefotiam $2 \mathrm{~g}$ /日を 6 日投与され, 術後 3 日に $20.3 \mathrm{mg} / \mathrm{d} l$ まで上昇した CRP は術後 7 日には $5.6 \mathrm{mg} / \mathrm{d} l$ まで低下し, 白血球数も術後 5 日目には正常化した. 術後 10 日に突然 $38.3^{\circ} \mathrm{C}$ の発熱が 出現し, 術後 13 日の検查所見で白血球数増加 $10040 / \mu l$, CRP $17.4 \mathrm{mg} / \mathrm{d} l$ と再上昇を認めた. IVH カテーテル感 染を疑い，直ちにカテーテル抜去し，カテーテル先端を 培養した. カテーテル抜去後, 発熱, 炎症所見は消失し, 術後 26 日目に退院となった. 血液培養は施行されなかっ た。

菌学的所見: 培盖 10 日月になって, IVH カテーテル 先端を入れた Brain Heart Infusion (BHI) 半流動培地 に酵母様真菌の増殖が認められた。形態的に Malassezia が疑われたので, Modified Dixon agarで継代培養する と，大きなコロニーが形成された（図）。また，コロニー は小さいものの oil 無添加の CHROMagar Candida ${ }^{\circledR}$, potato dextrose agar, Sabouraud agarにも3 週間目に なって菌の発育が認められ，同じ培地で継代培養が可能 であった. Tween assimilation test ${ }^{3)}$ を行うと, Tween 20,80 の周团に明暸な阻止円が形成され，その周囲に菌

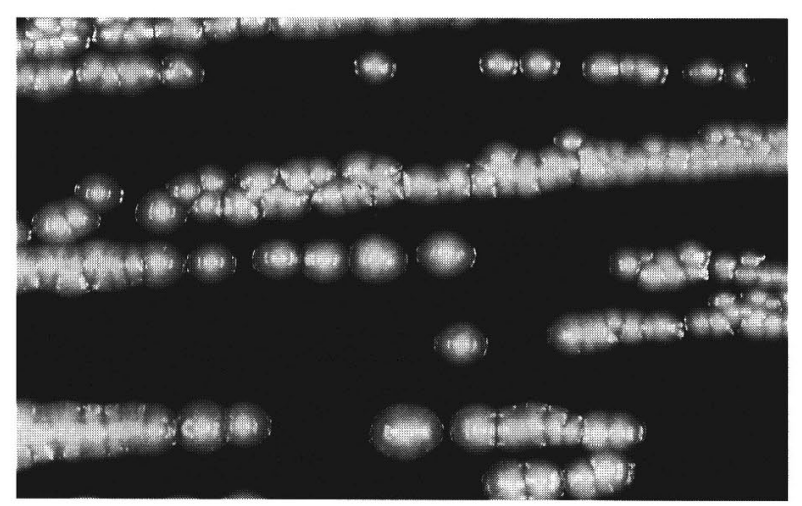

Fig. Colony appearance of $M$. sympodialis TW15001 (from this case) on modified Dixon's agar for 14 days.
の発育が認められるパターンを示し, M. sympodialis の type strain と一致していた. Internal transcribed spacer 1 regions（ITS1）領域の全塩基配列 $162 \mathrm{bp} の$ direct sequence を行ったところ4), type strain の DNA 配列と $100 \%$ 一致し，この菌はM. sympodialis であることが確認 された。

\section{考察}

Malassezia による中心静脈カテーテル感染症は小児科, 特に新生児室-neonatal intensive care unit (NICU) で 脂肪製剂を用いていたケースが多く $1,5,6)$ ，近年は院内感 染の outbreak 例も散見され ${ }^{1,5-7)}, M$. furfur 及び $M$. pachydermatis によるものが報告されている1, 5-7). 一方， M. sympodialis は動物，ヒ卜皮膚などから分離されてい るが2,3,8), その病原性については不明な点が多い． M. sympodialis がカテーテルから検出された報告はな く，本症例が初めてのヶースと考元られた。また， M. sympodialis は $M$. furfur と同様に脂質要求性があるとさ れるが2,3,8), 本菌は oil 無添加の potato dextrose agar, Sabouraud agarにも, 増殖は遅く, 脂質非要求性の $M$. pachydermatis ほどのコロニーを形成しないものの, 発育 を認め，加継代も可能であった. 脂質を添加していな いBHIに初代分離されたことと, 本症例に脂肪製剂が 使用されていなかった事実もこの性状を支持する．M. sympodialis は Tween 20,80 で明暸な発育阻止が認めら れるなど, M. furfur らの他の脂質要求性 Malassezia とは 明らかに異なっていることが知られている3). この機序 は不明であるが, M. furfur らとは脂質代謝機構が違う 可能性が示唆された. Malassezia に上る中心静脈カテー テル感染症は, 近年報告が相次いで扔り 1, 5-7), 検査室で Malassezia はカテーテル先端培養時に考慮せねばならな い菌の一つと考えられた。

\section{文献}

1) Marcon MJ, Powell DA: Human infections due to Malassezia spp. Clin Microbiol Rev 5: 101-109, 1992.

2) Guého E, Midgley G, Guillot J: The genus Malassezia with description of four new species. Antonie van Leeuwenhoek 69: 337-355, 1996.

3) Guillot J, Guého E, Lesourd M, et al.: Identification of Malassezia species. J Med Mycol 6: 103-110, 1996.

4) Makimura K, Tamura Y, Kudo M, et al.: Species identification and strain typing of Malassezia species stock strains and clinical isolates based on the DNA sequences of nuclear ribosomal internal transcribed spacer 1 regions. J Med Microbiol 49: 29-35, 2000.

5) Weibel SF, Mcneil MM, Pramanik A, et al.: Nosocomial Malassezia pachydermatis bloodstream infections in a neonatal intensive care unit. Pediatr Infect Dis J 13: 104-108, 1994.

6) Chang $\mathrm{HJ}$, Miller HL, Watkins $\mathrm{N}$, et al.: An epidemic of Malassezia pachydermatis in an intensive care nursery 
associated with colonization of health care workers' pet dogs. N Engl J Med 338: 706-711, 1998.

7) Barber GR, Brown AE, Kiehn TE, et al.: Catheterrelated Malassezia furfur fungemia in immunocompro- mised patients. Am J Med 95: 365-370, 1993.

8) Guého E, Ashbee HR, Van Belkum A, et al.: The role of Malassezia species in the ecology of human skin and as pathogens. Med Mycol 36(Suppl 1): 220-229, 1998.

\section{A Case of Central Venous Catheter-related Infection with Malassezia sympodialis}

Ken Kikuchi ${ }^{1}$, Yoshiko Fujishiro ${ }^{2}$, Kyoichi Totsuka ${ }^{1}$, Akiyoshi Seshimo ${ }^{3}$, Shingo Kameoka ${ }^{3}$, Koichi Makimura ${ }^{4}$, Hideyo Yamaguchi ${ }^{4}$

${ }^{1}$ Department of Infectious Disease,

${ }^{2}$ Department of Laboratory Medicine,

${ }^{3}$ Department of Surgery, Tokyo Women's Medical University,

8-1 Kawada-cho, Shinjuku-ku, Tokyo 162-8666, Japan

${ }^{4}$ Teikyo University Institute of Medical Mycology

We report a 63-year-old male with central venous catheter-related infection caused by Malassezia sympodialis after total gastrectomy for a gastric cancer. He had fever and his leukocyte counts and C-reactive protein were elevated 14 days after his operation. After his central venous hyperalimentation catheter was removed, the inflammatory signs immediately disappeared, suggesting an intravenous catheterralated infection. A yeast-like fungus was cultured in brain-heart infection semi-solid agar ten days later, and was diagnosed morphologically as Malassezia sp. This strain was identified as $M$. sympodialis by Tween assimilation test and was confirmed by whole-sequence of internal transcribed spacer 1 regions (ITS1). This is the first report of catheter-related infection caused by $M$. sympodialis. This strain grew and was subcultured on CHROMagar Candida ${ }^{\circledR}$, potato dextrose agar and Sabouraud agar. There have been no reports of such a lipid-independent Malassezia sp. except for $M$. pachydermatis. The mechanism of lipid independence of this strain is undetermined and future work is needed. Malassezia sp. is receiving increased attention as an etiologic pathogen of catheter-related fungemia in clinical microbiology laboratories and infectious disease sections. 